\title{
Ownership Structure and Dividend Policy at LQ45 Companies of the Indonesian Stock Exchange
}

\author{
Abdul Chotib Nasih ${ }^{1, *}$, Gatra Gumilang ${ }^{1}$, Alkhomah $^{1}$, Siti Nurrohmah $^{1}$, Dwi Endah ${ }^{1}$ \\ ${ }^{1}$ Management Department, Faculty of Economics, Universitas Negeri Semarang \\ *Corresponding Author. Email: nasihgenie@gmail.com
}

\begin{abstract}
This study aims to examine the effect of ownership structure on dividend policy. The independent variable used in this study is the ownership structure which is divided into managerial stock ownership (MSO) and institutional stock ownership (INST). The dependent variable used is the dividend policy measured using the dividend payout ratio (DPR). The moderating variable in this research is BUMN company. The sample used in this study is companies listed on the LQ45 stock market index on the Indonesia Stock Exchange (IDX) in the 2016-2018 period. The number of samples obtained was 45 companies. This study uses secondary data in the form of annual financial reports that are accessed through the official website of the IDX. Techniques for analyzing data are using multiple linear regression methods and SPSS data processing applications. Empirical results of this study indicate that managerial stock ownership (MSO) has a negative and not significant effect; then for institutional ownership (ISO) positive and significant effect; Managerial share ownership (MSO) moderated by BUMN companies has a negative and not significant effect; meanwhile, for institutional share ownership (ISO) has positive and significant effect on dividend policy.
\end{abstract}

Keywords: Dividend policy, Institutional Ownership, Managerial Ownership, Dividend Payout Ratio

\section{INTRODUCTION}

The decision on dividend payment is a fundamental component of company policy and has become an important issue in the financial literature. This decision it has to do with decision expenditure, which is the company's decision to distribute dividends to stockholders have a purpose in order to improve shareholder welfare. Agency conflict is a conflict that occurs between managers (stakeholders) and shareholders which is a concept of free cash flow. This conflict can occur because managers tend to attach importance to personal well-being rather than the wellbeing of shareholders by maximizing their own advantage. That free cash flow is the reason companies to pay dividends [1].

Increased Dividend Payout Ratio (DPR) can generate free cash flow little, so as to be able to finance the investment the manager must seek outside funding. On investment, the dividend payment is an element that very important because it becomes an attraction for investors. Dividend policy considers the payout carried out by the top shareholder's contribution in providing funds for the company and compensation to support inherent business risk. Dividend policy can affect the value of the company because dividend and growth policies the company must be balanced. That structure company ownership has a role important in dividend policy as it can reduce the associated agency costs with agency theory [2].

We tested the ownership structure against dividends using two theories, namely the theory of results and the theory of substitution [3]. Theory of result predicts that the owner stakeholders are inside the company in opportunities will take advantage of dividend policies for personal gain. Therefore, based on the result theory states that owner-controlled companies will pay lower dividends. Whereas in the opposite theory substitute with a result theory statement. In theory, substitute predicts that a firm that is controlled by non-owner will take personal benefits later after dividend distribution to reduce conflict between the owners. It can be said that companies controlled by non-owners will distribute higher dividends rather than companies controlled by the owner.

There have been many previous studies that examines the effect of structure ownership of dividend policy. Identifying previous research on the effect of ownership structure on dividend policy finds structure ownership has a positive effect on dividend policy that occurs in the company registered with Nordic. Shows that the ownership structure and Dividend policy has that effect positive [2]. These results support the structural 
relationship between ownership and payment of dividends on a basis consistent. Judging from the ownership structure institutional, institutional ownership structure companies have a tendency to pay dividends are higher [4]. In addition, research results were found that increasing ownership of managerial stock will reduce the rate of dividend distribution due to the tendency to be over do retained earnings [2]. Furthermore, managerial share ownership could reduce the rate of Agency Theory [5]. Agency Theory problems occur because of differences in interests regarding the use of returns generated by the company. Differences in ownership dominance of the company can influence the rate from agency theory and also policies that will be given to a company. This matter support researchers to do testing the ownership structure against company dividend policy with BUMN companies as a moderating variable.

This research was conducted to identify the extent to which the company makes decisions on dividend policy in the context of agency problems with focuses on emerging markets namely in Indonesia. This research is empirical will examine how the ownership role company against dividend policy in LQ45 companies and stateowned companies which are listed on the IDX. Focus researchers in this study are knowing the influence of institutional share ownership (institutional ownership), and ownership managerial ownership on dividend policy decisions LQ45 company with BUMN company as the moderating variable listed in Indonesia Stock Exchange from 2016 to 2018. In this study, researchers have some conjecture about the influence of the structure ownership of dividend policy.

First, we tested it on managerial ownership. Ownership managerial is the proportion of that share owned by management. Researchers suspect that managerial ownership will tend to reduce the dividend payout rate. This is based on the will to decide retained earnings for the sake of increasing capital company. This assumption is supported by research [6] which states that the ownership of shares owned by the ranks management influences dividend policy and company performance small. The same results were obtained from the research entitled The Impact of Ownership Structure on Dividend Policy Evidence from Emerging Markets Pakistan's KSE-100 Index, which stated that managerial shareholdings are increasing will decrease the payout dividends and lowering agency theory. Based on this explanation, the researcher finds the first hypothesis is:

H1: Managerial ownership is influential negative on dividend distribution company

Second, we tested on ownership institutional. Institutional ownership is the share ownership that is owned by non-bank institutions in the company. Dominant institutional ownership share ownership of the company will be considered the advantages for the institution that invests the funds. Guess what second that the company that owns institutional ownership tends to make a dividend distribution that is supported with the research of [7]. This research is supported by research [8] entitled Family Control, Institutional Environment and Cash Dividend Policy: Evidence From China which states that there is a negative relationship between institutional share ownership with dividend payout. This is also in line with research [4] entitled Dividend Policy and Ownership Structure in the Netherlands, which discovered that institutional ownership has a negative effect on dividend policy. Next research [9] entitled Effect of Institutional Ownership on Dividend: An Agency-Theory-Based Analysis states that the Dividend Payout Ratio has a positive relationship with ownership institutional. But the results of these studies contrary to research [10] entitled The Impact of Institutional Ownership and Dividend Policy on Stock Returns and Volatility: Evidence from Egypt which found that institutional ownership has a negative effect on the ratio dividend payment. Further research [4] entitled Institutional Ownership, Managerial Ownership, and Dividend Policy in Bank Holding Company found the result that the ownership structure is good managerial ownership and ownership institutional has a negative influence on dividend policy. Some of the research shows excellent results differently. Therefore, researchers build the second hypothesis is:

H2: Institutional ownership has a positive effect on dividend distribution company

Third, we tested ownership managerial in stateowned companies (BUMN) registered with the company LQ45. In state-owned companies usually, they will be more sensitive to government policies than they are non BUMN company. Therefore, companies that belong to the group Most of the owners of BUMN are government, they have bargaining power which is higher compared to non-BUMN companies in the GMS. The thing that affects the Dividend Per Share will differ between stateowned companies and non BUMN. We suspect that is getting little managerial ownership on BUMN companies, the higher the share dividend. Because it is a state-owned company that wants welfare for investors. Thus, dividends awarded to investors will be higher. Therefore, Researchers build a third hypothesis, namely:

H3: Managerial ownership has a weak negative effect to dividend policy moderated by company owned state (BUMN).

Fourth, we tested ownership institutional in stateowned companies (BUMN) registered with the company LQ45. We suspect that it is getting higher institutional ownership of the company state-owned (BUMN), the higher it is dividends distributed. This can happen because the company is owned by the government or state aims to increase the prosperity of society. Because it's a state-owned company generally will pay high dividends to achieve the country's goals in doing development. Based on the Ministerial Regulation Stateowned enterprises number: PER-01 / MBU / 2011 
regarding Good Corporate Governance (Good Corporate Governance) in the company state-owned enterprises (BUMN) that provide obligations for BUMN companies to implementing GCG. This is mandatorily done to improve corporate value to create value for shareholders. Hence, researchers build the fourth hypothesis, namely:

H4: Institutional ownership matters strong positives for dividend policy moderated by the proprietary company state (BUMN).

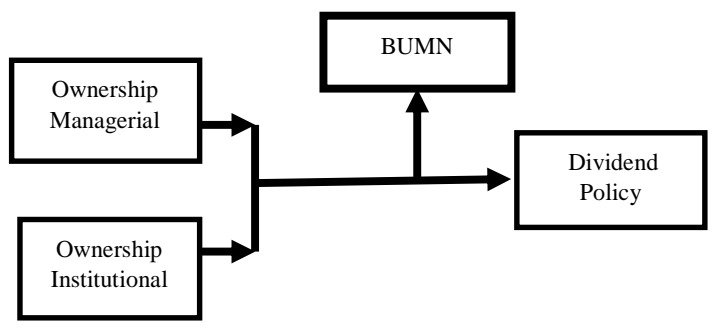

Figure 1. Research Model

\section{RESEARCH METHODS}

The sample used in the study is using the LQ company population 45 listed on the Indonesia Stock Exchange from 2016-2018. Sampling technique using purposive sampling technique with criteria for companies that have information complete related to managerial share ownership (MSO) and institutional shareholdings (ISO) as well as some other information required in the calculation process. amount LQ45 companies listed on the Stock Exchange Indonesia as many as 45 companies. the amount the sample firms were obtained based on 36 criteria has been set company.

The data source of this research is secondary data namely data obtained from companies that including the LQ45 company registered at Indonesia Stock Exchange 2016-2018. Data used are financial statements yearly company earned through the website (www.idx.go.id). The technique for analyzing data using processing applications SPSS data. While the method used to analyze the data in this study using descriptive statistical methods and testing multiple regression.

The variables in this study were divided into three types, namely the dependent variable, the independent variable, and the moderating variable. The dependent variable in this study is dividend policy. Independent variable used in the study these are managerial ownership and institutional ownership. Moderating variable in research, namely state-owned companies.

Dividend policy as a variable dependent on this research is proxied with the DPR (Dividend Payout Ratio). Have tested research on the influence of ownership structure on dividend policy by using a measure dividend payout ratio [10]. The DPR calculation formula is the dividend per net income.

Ownership is defined as the amount of share ownership owned by the management that is actively participating in the retrieval process decisions [11]. According to Afza and Mirza (2010), ownership managerial is defined as a percentage share ownership owned by ranks executives and members of the Board of Directors (BOD). Measurement of this variable with add up the shares owned by the party management at the end of the year divided by the number of shares outstanding in the market. Variable Managerial ownership is measured by the formula:

$$
\mathrm{MSO}=\frac{\text { Number of managerial shareholdings }}{\text { Number of company shares }}
$$

Institutional Ownership Institutional ownership is defined as a proportion of share ownership measured by percentage and owned by institutions at the end of the year period. Ownership shares held by the institution include investment companies, insurance companies, banks, and other institutional shareholdings. The institutional ownership variable is measured with the formula

$$
\text { ISO }=\frac{\text { Number of institutional shareholdings }}{\text { Number of company shares }}
$$

The moderating variable is a variable that affects the relationship between variables dependent and independent variables, either strengthen or weaken. In this research state-owned companies (BUMN) to become a moderating variable. According to Article 1 paragraph (1) Law, Number 19 of 2003, State-Owned Company (BUMN) is business entities that are mostly or wholly the capital is owned by the State through direct participation and originating from the wealth of the separated State.

Variable This moderation is measured using variables dummy, which gives a value of 1 in state-owned companies (BUMN) and a value of 0 on non-state-owned companies (non BUMN).

The author uses a regression model multiple to test the hypothesis in research. The regression model formed is: $\mathrm{YDPR}=\alpha+\beta 1 \mathrm{X} 1+\beta 2 \mathrm{X} 2+\beta 3 \mathrm{X} 3$
$\mathrm{Y}$ : Dividend policy (DPR)
$\alpha$ : Constant value
$\beta$ : Regression coefficient
$\mathrm{X} 1$ : Managerial share ownership (MSO)
$\mathrm{X} 2$ : Institutional share ownership (ISO)
X3 : BUMN

\section{RESEARCH RESULT}

This study uses data secondary annual report of the company listed on the IDX which is included in LQ45 group for the 2016 - 2018 period taken from the official website of the Stock Exchange Indonesia (www.idx.go.id) uses technique sampling technique purposive sample from the total sample totaled 45 companies obtained 36 companies that have complete information related to managerial share ownership 
(MSO) and institutional share ownership (ISO) as well some other necessary information on calculation process.

Table 1. Descriptive Statistics

\begin{tabular}{|l|l|l|l|l|l|l|l|l|}
\hline Variabel & Mean & Sum & Minimum & Maximum & Range & Std Dev & Skewnes & $\mathrm{N}$ \\
\hline DPR & .1384 & 86.52 & .00 & 1.33 & 3.38 & .78536 &. .556 & 108 \\
\hline MSO & .1369 & 6.48 & .00 & .30 & 7.31 & 2.47643 & .034 & 108 \\
\hline ISO & .5325 & 53.79 & .00 & 80.02 & 4.17 & .47550 & -4.997 & 108 \\
\hline Moderasi & .0040 & .43 & .00 & .06 & .06 & .01374 & 3.461 & 108 \\
\hline Manajerial & 1.00 & 108 & 1.00 & 1.00 & 0.00 & .000 &. & 108 \\
\hline Institusional & .00 & 0 & .00 & .00 & 0.00 & .000 &. & 108 \\
\hline
\end{tabular}

From table 1, it gives the results descriptive statistics about the picture companies listed on the IDX which are included in LQ45 regarding the maximum value, minimum, median, average under test using these descriptive statistics.

The dependent variable in this study is the DPR which is obtained from dividends divided by net income. Table 1 shows that the mean of DPR value 0.1384 or $13.84 \%$ which means that the company's dividend payment listed on the IDX which is included in LQ45 in the 2016 - 2018 observation year, namely $13.84 \%$ with a statistical minimum value of $0.00 \%$ and the maximum statistical value is $133 \%$. As for the independent variable on Ownership Institutional Ownership Managerial Policy Dividend BUMN. This research is MSO (Managerial Share Ownership) and IO (Institutional Share Ownership). MSO is the value obtained from share ownership in the company is divided by the number of shares outstanding in the year observation. Based on the results of statistics descriptive average MSO value of 0.1369 or the proportion of share ownership managerial amounting to $13,699 \%$ with value a minimum of $0.00 \%$ and a maximum value $30 \%$ which means that the proportion spread is between $0.00 \%-30 \%$.

The second independent variable is institutional ownership / ISO is obtained from comparison between total ownership shares of the company by the number of shares outstanding in the related year. From the descriptive statistical test data obtained a statistical average of 0.5325 which means that the proportion of ownership institutional shares amounted to $53.25 \%$ with a value minimum 0.00 or $0.00 \%$ and value a maximum of 0.8002 or $80.02 \%$ which is it can be interpreted that the distribution of proportion data between $0.00 \%$ $80.02 \%$.

The third independent variable is the moderating variable. This moderating variable is the moderate (connecting) variable for the variable independent with the DPR. Moderating variable obtained from the dummy type of company where BUMN companies are coded 1 and non BUMN companies are given code 0 . Next is calculated by the formula ISO X MSO X BUMN (Code). In the descriptive statistical test in table 1 , the average value is 0.040 with a SUM value of 0.43 . Minimum value 0.00 and a maximum value of 0.06 . Then there are managerial variables as a dummy for the majority of share ownership where if the majority of share ownership is owned by managerial, it is given a value of 1 and if not managerial, the score is 0 . Award predicate of majority is when proportion shares held above $50 \%$. The average in this dummy variable is 1 meanwhile the maximum value is 1 and the minimum value is 0 .

The last variable in this research is the institutional dummy variable where if the majority of share ownership is owned institutional is given a value of 1 and if the majority ownership is not institutional then it is given value 0 . In the analysis, results are average institutional 1 with a maximum value of 1 and a minimum value of 0 . In this study majority ownership of all shares is institutional ownership

In this study, researchers use the classic assumption test to ensure that the data distribution is normal, meet the assumption of linearity, no heteroscedasticity, nonmulticollinearity, and there is no autocorrelation. However, on data normality, testing researchers experienced some obstacles, namely the distribution of data is not normal and happens out layer. So, for normalizing the distribution of data, researchers remove the out layer. So that it can performed multiple regression test and obtained the outputs are as follows:

Table 2. Multiple regression test obtained the model DPR

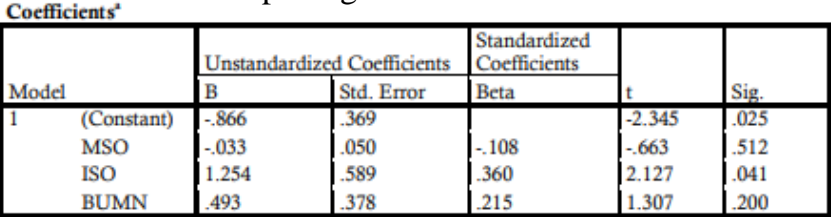

a. Dependent Variable: LN_DPR

From the results of the multiple regression test obtained the model DPR $=-0.866+(-0.033 \mathrm{MO})+$ $1,254 \mathrm{IO}+0.493 \mathrm{BUMN}$. Based on table 2 it is known that the value of share ownership managerial / MSO of -0.033 with a value significant probability of 0.512 . This matter means that share ownership managerial / MSO has negative and no effect significant towards DPR policy, or it can be it is said that the greater the MSO value than the smaller or the lower dividend distribution rate (DPR) as well otherwise. This is in line with the research first did Ullah. (2012) which mentions that the increased managerial level share ownership will reduce the dividend payout rate due to managerial has a tendency to more do retain earnings because of managers more focused on monitoring decisions company done by that manager itself to protect its investment.

On this managerial ownership (MSO) obtained tcount -0.033 with a value significance of 0.783 which can be interpreted that managerial share ownership (MSO) has a negative effect on the dividend's payout ratio of 0.033 . A negative value means the greater the proportion of managerial share ownership in a company, the smaller the dividend payout ratio paid. This research not according to prior research that [12] who stated that manager ownership has an effect positive towards DPR policies [6]. 
Institutional / ISO share ownership has a positive regression coefficient of 1.254 and a significant probability value of 0.041 , yes it means that share ownership institutional / ISO positive and influence significantly towards DPR policy. Could it is assumed that the increase over institutional share ownership can increase the dividend payout rate. The thing this is not in line with that research done by [13] which mentions that the institutional ownership variable has a negative effect on dividends payout ratio (DPR) in this study has a positive value of 0.028 .

Furthermore, the BUMN variable where this variable is a moderating variable company that is a company which is BUMN companies are given a value of 1 and if non-BUMN is given a value of 0 . Obtained value 0.493 which means that ownership of the company has a positive effect on DPR policies with a significance of 0.200 assumed that the moderating variable BUMN has a positive and insignificant effect against DPR policies.

In addition, the ISO obtained a t-count equal to 0.663 with a significance value of 0.512 at the 0.05 significance level. This matter it can be interpreted that the hypothesis exists influence of institutional share ownership acceptance of DPR policies, and based on the level of significance obtained the result that the influence of the ownership variable significant institutional share against payout ratio policy. That there was an influence positive between ownership structures institutional to dividend payout policy ratio (DPR) by the company. Para shareholders mainly on ownership institutional like a share higher according to the coefficient sign positive. It is said that, if any the parallels between the interests of managers and shareholder in this ownership institutional stock one of which will be influence in policymaking conducted dividend payout ratio (DPR) [12]

Table 3. value of $\mathrm{R}$ square from the independent variable

Model Summary
\begin{tabular}{|l|l|l|l|l|}
\hline Model & $R$ & R Square & $\begin{array}{l}\text { Adjusted } \\
\text { Square }\end{array}$ & $\begin{array}{l}\text { Std. Error of } \\
\text { the Estimate }\end{array}$ \\
\hline 1 & $.357^{\mathrm{2}}$ & .128 & .053 & .75681 \\
\hline
\end{tabular}

a. Predictors: (Constant), BUMN, MO, IO

Based on these tests the value of $\mathrm{R}$ square is 0.128 or stated that as many as $12.8 \%$ of the variables the dependent dividend policy is described by the independent variable is ownership managerial / Managerial Ownership (MSO), institutional / Institutional ownership variable Ownership (ISO) and then the remaining $87.2 \%$ is explained by other variables outside

\section{b. Dependent Variable: DPR}

Table 4. Multiple regression test obtained the model DPR

\begin{tabular}{|c|c|c|c|c|c|c|}
\hline \multirow{2}{*}{\multicolumn{2}{|c|}{. }} & \multicolumn{2}{|c|}{ Unstandardized Coefficients } & \multirow{2}{*}{ 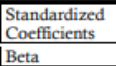 } & & \multirow[b]{2}{*}{ Sig. } \\
\hline & & & Std. Emor & & & \\
\hline & (Constant) & -826 & 377 & & -2.190 & 1.036 \\
\hline & & -.024 & .053 & -078 & -458 & .650 \\
\hline & & & & .353 & $2,0.060$ & \\
\hline & Modera & 1092 & 1545 & .398 & 1.247 & $\mid \begin{array}{l}2121 \\
507\end{array}$ \\
\hline
\end{tabular}

From the results of the multiple regression test with moderation of ownership of the company obtained model $\mathrm{DPR}=-0,826+(-0,024 \mathrm{MSO})+1,229 \mathrm{ISO}+$ $0,913 \mathrm{BUMN}$ In the regression test with moderation this is the same with the regression test in Table 2 where MSO has a positive effect on DPR policies, while ISO and BUMN have a positive effect against the DPR. While the moderating variable obtained from the calculation of MSO X ISO X BUMN is negative by level significance of 0.507 which means insignificant.

\section{c. Predictors:(Constant), Moderation, MO, IO, BUMN}

Table 5. Regression testing with moderation

Model Summary
\begin{tabular}{|l|l|l|l|l|}
\hline Model & R & R Square & $\begin{array}{l}\text { Adjusted } \\
\text { Square }\end{array}$ & $\begin{array}{l}\text { Std. Error of } \\
\text { the Estimate }\end{array}$ \\
\hline 1 & $.373^{n}$ & .139 & .038 & .76282 \\
\hline
\end{tabular}

Based on regression testing with moderation of company ownership The BUMN obtained the R square value is 0.139 or stated that as much as $13.9 \%$ the dependent variable dividend policy is described with the independent variable, namely ownership managerial/ Managerial Ownership (MSO), institutional/ Institutional ownership variable Ownership (ISO), BUMN, and variables moderation then the rest is $86.1 \%$ described by other variables outside the model. Based on the comparison of the $\mathrm{R}$ square value on multiple regression testing without moderation with regression test with moderating variables obtained a higher $\mathrm{R}$ square value, indicates that this moderating variable influencing DPR policies, although the effect is insignificant.

\section{CONCLUSION}

Based on the research result, it can be concluded that Managerial Share Ownership (MSO) has a negative and insignificant effect on the dividend policy. It means the higher the proportion managerial shareholdings, the less dividends paid and vice versa. Manager who is also a shareholder tends to prioritize personal gain compared to interests outside the company.

Then for institutional share ownership (ISO) has a positive and significant effect on dividend policy, which means that the greater the proportion of institutional share ownership, the greater the dividend paid. This is because a large proportion of institutional share ownership provides oversight of the manager's performance and as an outside controller of the company's dividend policy.

Managerial Share Ownership (MSO) moderated by state-owned companies has a negative and insignificant effect against the DPR policy, which means that the greater the managerial ownership moderated by stateowned companies then, the smaller DPR that was distributed. Same goes for managerial shareholdings that are not moderated. 
Meanwhile, for share ownership institutional (ISO) and positive effect significant, which means that it is getting bigger the proportion of ISO ownership is getting bigger too The DPR is distributed and vice versa. This is also due to the majority share ownership in BUMN companies owned by the institution itself in this regard government has dominant control over company operations.

\section{REFERENCES}

[1] Y. Thanatawee, "Ownership Structure and Dividend Policy: Evidence from Thailand," Int. J. Econ. Financ., vol. 5, no. 1, pp. 121-132, 2012, doi: 10.5539/ijef.v5n1p121.

[2] H. Ullah, A. Fida, and S. Khan, "The Impact of Ownership Structure on Dividend Policy Evidence from Emerging Markets KSE-100 Index Pakistan," Int. J. Bus. Soc. Sci., vol. 3, no. 9, pp. 298-307, 2012.

[3] C. Ostergaard and D. C. Smith, "Corporate Governance Before There Was Corporate Law," no. 3, pp. 1-63, 2011.

[4] M. Firth, J. Gao, J. Shen, and Y. Zhang, "Institutional stock ownership and firms' cash dividend policies: Evidence from China," J. Bank. Financ., vol. 65, pp. 91-107, 2016, doi: 10.1016/j.jbankfin.2016.01.009.

[5] A. Ngo, H. Duong, T. Nguyen, and L. Nguyen, "The effects of ownership structure on dividend policy: Evidence from seasoned equity offerings (SEOs)," Glob. Financ. J., vol. 44, no. 2017, p. \#pagerange\#, 2020, doi: 10.1016/j.gfj.2018.06.002.

[6] Z. Chen, Y. L. Cheung, A. Stouraitis, and A. W. S. Wong, "Ownership concentration, firm performance, and dividend policy in Hong Kong," Pacific Basin Financ. J., vol. 13, no. 4, pp. 431449, 2005, doi: 10.1016/j.pacfin.2004.12.001.

[7] J. M. San Martín Reyna, "Estructura de propiedad y su efecto en la política de dividendos en el contexto mexicano," Contaduria y Adm., vol. 62, no. 4, pp. 1199-1213, 2017, doi: 10.1016/j.cya.2015.12.006.

[8] Z. Wei, S. Wu, C. Li, and W. Chen, "Family control, institutional environment and cash dividend policy: Evidence from China," China J. Account. Res., vol. 4, no. 1-2, pp. 29-46, 2011, doi: 10.1016/j.cjar.2011.04.001.

[9] K. Chang, E. Kang, and Y. Li, "Effect of institutional ownership on dividends: An agencytheory-based analysis," J. Bus. Res., vol. 69, no. 7, pp. 2551-2559, 2016, doi: 10.1016/j.jbusres.2015.10.088.

[10] T. Afza and H. H. Mirza, “Ownership Structure and Cash Flows As Determinants of Corporate Dividend Policy in Pakistan," Int. Bus. Res., vol. 3, no. 3, p. 210, 2010, doi: 10.5539/ibr.v3n3p210.
[11] D. N. Vidyantie and R. Handayani, "the Analysis of the Effect of Debt Policy, Dividend Policy, Institutional Investor, Business Risk, Firm Size and Earning Volatility To Managerial Ownership Based on Agency Theory Perspective," J. Bisnis dan Akunt., vol. 8, no. 2, pp. 19-33, 2006, [Online]. Available: http://jurnaltsm.id/index.php/JBA/article/view/112.

[12] F. Wuisan, F. Randa, and L. Lukman, "Pengaruh Struktur Kepemilikan Terhadap Kebijakan Dividen Perusahaan," Simak, vol. 16, no. 02, pp. 119-141, 2018, doi: 10.35129/simak.v16i02.39.

[13] O. G. Reeves, I. S. Saerang, and J. B. Maramis, "Uji Akurasi Support Resistance Berbasis Data Candlestick Pada Industri Pertambangan Yang Terdaftar Di Indeks Lq45," JMBI UNSRAT (Jurnal Ilm. Manaj. Bisnis dan Inov. Univ. Sam Ratulangi)., vol. 6, no. 1, pp. 1-10, 2019, doi: 10.35794/jmbi.v6i1.24269. 